\title{
17. MAGNETIC PROPERTIES OF PLUTONIC ROCKS FROM THE CENTRAL NORTH ATLANTIC OCEAN ${ }^{1}$
}

\author{
Guy M. Smith and Subir K. Banerjee, Department of Geology and Geophysics, University of Minnesota ${ }^{2}$
}

\begin{abstract}
Ten samples of gabbro and peridotite, with varying degrees of serpentinization, were studied by magnetic techniques and reflected light microscopy. Evidence from these methods suggests that the natural remanent magnetization is primarily of chemical origin. It is generally weak for the gabbros and much stronger for the peridotites. This difference is offset by the fact that the peridotites have generally lower magnetic stability and Koenigsberger ratios. There is a considerable variation in both magnetic parameters and petrology even among closely spaced samples, which suggests that some combination of source heterogeneity and tectonic mixing was involved in the production of these rocks. However, the small number of samples makes this conclusion tentative. There may also have been significant postemplacement alteration involved. All samples show a significant anisotropy of weak field susceptibility that appears to be related to deformation. This anisotropy may be useful in defining petrofabrics.
\end{abstract}

\section{INTRODUCTION}

In addition to the expected extrusive basalts, plutonic rocks (principally peridotites and gabbros) were recovered from Holes 556, 558, and 560. This paper reports on the magnetic characteristics of these plutonic rocks. These samples represent one of only a few suites recovered from normal crust (see Dunlop and Prevót, 1982), but may provide some interesting information, however murky, about the magnetic properties of the deeper parts of the oceanic crust. In addition, they may offer some insight into the nature of tectonic activity associated with the Mid-Atlantic Ridge.

We measured a number of standard magnetic parameters including:

1. intensity, direction, and stability of natural remanent magnetization (NRM);

2 . intensity and stability of anhysteretic remanent magnetization (ARM);

3. hysteresis loop parameters; saturation magnetization, $\mathrm{J}_{\mathrm{s}}$; saturation remanence, $\mathrm{J}_{\mathrm{rs}}$; coercivity, $\mathrm{H}_{\mathrm{c}}$; remanent coercivity, $\mathrm{H}_{\mathrm{cr}}$; and paramagnetic susceptibility, $\chi_{\mathrm{p}}$;

4. weak field susceptibility, $\chi_{0}$; and

5. Curie temperature, $T_{c}$, ratio of the magnetization before heating to the magnetization after heating, $\mathrm{J}_{\mathrm{f}} / \mathrm{J}_{\mathrm{i}}$, and thermomagnetic curve analysis.

We also did some preliminary analysis of polished thin sections using both reflected and transmitted light.

\section{METHODS}

Except as noted, the techniques used here are the same as described in the previous paper (Smith and Banerjee, this volume).

A modified sample holder was constructed for the susceptibility bridge in order to measure anisotropy. This permitted rotation of disk-

\footnotetext{
${ }^{1}$ Bougault, H., Cande, S. C., et al., Init. Repts. DSDP, 82: Washington (U.S. Govt. Printing Office).

2 Address: Department of Geology and Geophysics, University of Minnesota, Minneapolis, Minnesota 55455.
}

shaped samples about an axis perpendicular to the measurement axis. Readings were taken every $20^{\circ}$ for a complete rotation. Microscopy was done on a Zeiss microscope with oil immersion lenses and a Polaroid camera.

\section{RESULTS}

\section{Natural Remanence}

There are basically two types of rock discussed in this report, peridotites and gabbros, which both have varying degrees of serpentinization. NRM intensities of peridotites $\left(\mathrm{J}_{\mathrm{N}}\right)$ tend to be somewhat higher than gabbros, although there is some overlap (Table 1). Median demagnetizing fields $\left(\mathrm{MDF}_{\mathrm{N}}\right)$ are substantially larger for gabbros than peridotites. The directional data are not summarized so readily. The two gabbros from Site $\mathbf{5 5 6}$ were not consistent with each other or with the overlying basalts. Two of the serpentinites from Hole 558 had normal inclinations and the other two had the same value but reversed inclination. Comparison with the overlying basalts is uncertain, because they also show both normal and reversed directions.

The Site 560 samples show a fair amount of consistency and are reasonably close to the axial dipole value for the site (about $55^{\circ}$ ). Most of the samples have fairly straight univectorial demagnetization curves after about 100-150 Oe (Fig. 1A). The low coercivity component is probably viscous, as it is generally close to the current inclination at the site. Only one sample definitely shows multicomponent behavior (560-3-1, 9-12 cm) (Fig. 1B). This would suggest acquisition of remanence in two episodes separated by a significant time lapse $(\sim 1000 \mathrm{yr}$.) and/or tectonic activity. Curiously, the low coercivity "secondary" component is low inclination, whereas it is the "primary" component that is close to the present field.

Koenigsberger ratios (Q) varied from 0.02 to 19.5 (Table 1). They were generally higher for the gabbros than the peridotites. 
Table 1. Remanent properties.

\begin{tabular}{|c|c|c|c|c|c|c|c|c|c|c|}
\hline $\begin{array}{l}\text { Core-Section } \\
\text { (interval in cm) }\end{array}$ & $\begin{array}{c}\mathrm{J}_{\mathrm{N}} \\
\left(\mathrm{emu} \cdot \mathrm{cm}^{-3}\right)\end{array}$ & $\begin{array}{c}\mathrm{I} \\
\left({ }^{\circ}\right)\end{array}$ & $\begin{array}{c}\mathrm{MDF}_{\mathrm{N}} \\
(\mathrm{Oe})\end{array}$ & $\begin{array}{c}\mathrm{J}_{\mathrm{A}} \\
\left(\mathrm{emu} \cdot \mathrm{cm}^{-3}\right)\end{array}$ & $\begin{array}{l}\mathrm{MDF}_{\mathrm{A}} \\
(\mathrm{Oe})^{\mathrm{a}}\end{array}$ & $\frac{\mathrm{J}_{\mathrm{A}}}{\mathrm{J}_{\mathrm{N}}}$ & $\frac{\mathrm{MDF}_{\mathrm{A}}}{\mathrm{MDF}_{\mathrm{N}}}$ & $\left(\mathrm{emu} \cdot \mathrm{cm}^{\frac{x_{0}}{-3}} \cdot \mathrm{Oe}^{-1}\right)$ & Q & Description \\
\hline \multicolumn{11}{|l|}{ Hole 556} \\
\hline $14-2,29-32$ & $3.51 \times 10^{-4}$ & +51 & 400 & $1.17 \times 10^{-2}$ & $100 \%$ & 33 & $>2.5$ & $9.85 \times 10^{-5}$ & 7.1 & Gabbro \\
\hline $14-2,140-143$ & $1.53 \times 10^{-4}$ & +12 & 390 & $3.64 \times 10^{-3}$ & $88 \%$ & 24 & $>2.6$ & $9.27 \times 10^{-5}$ & 3.3 & Gabbro \\
\hline \multicolumn{11}{|l|}{ Hole 558} \\
\hline $41-2,61-64$ & $2.30 \times 10^{-4}$ & -41 & 211 & $2.22 \times 10^{-3}$ & 165 & 9.65 & 0.78 & $1.13 \times 10^{-3}$ & 0.4 & Peridotite \\
\hline $41-2,54-57$ & $4.20 \times 10^{-4}$ & -41 & 161 & $3.71 \times 10^{-3}$ & 150 & 8.83 & 0.93 & $9.10 \times 10^{-4}$ & 0.9 & Peridotite \\
\hline $41-2,109-112$ & $5.39 \times 10^{-3}$ & +41 & 129 & $9.54 \times 10^{-3}$ & 150 & 1.77 & 1.16 & $4.72 \times 10^{-3}$ & 2.3 & Peridotite \\
\hline $43-1,8-11$ & $2.62 \times 10^{-3}$ & +42 & 74 & $2.62 \times 10^{-3}$ & 110 & 1.00 & 1.49 & $5.44 \times 10^{-3}$ & 1.0 & Peridotite \\
\hline \multicolumn{11}{|l|}{ Hole 560} \\
\hline $3-1,9-12$ & $5.00 \times 10^{-4}$ & -45 & 350 & $4.67 \times 10^{-4}$ & 500 & 0.93 & 1.43 & $5.12 \times 10^{-5}$ & 19.5 & Gabbro \\
\hline $3-1,21-24$ & $1.53 \times 10^{-5}$ & -38 & 611 & $2.85 \times 10^{-4}$ & 500 & 19.0 & 0.82 & $3.08 \times 10^{-5}$ & 0.99 & Gabbro \\
\hline $5-1,98-101$ & $3.12 \times 10^{-4}$ & -65 & 154 & $1.30 \times 10^{-1}$ & 160 & 417.0 & 2.46 & $2.68 \times 10^{-2}$ & 0.02 & Peridotite \\
\hline $5-1,109-112$ & $1.10 \times 10^{-3}$ & -64 & 144 & $1.26 \times 10^{-2}$ & 150 & 11.0 & 1.04 & $5.50 \times 10^{-3}$ & 0.40 & Peridotite \\
\hline \multicolumn{11}{|l|}{ Averages } \\
\hline Gabbro & $2.55 \times 10^{-4}$ & - & 438 & $4.02 \times 10^{-3}$ & $>750$ & 19.2 & $>1.84$ & $6.83 \times 10^{-5}$ & 7.7 & \\
\hline Peridotite & $1.68 \times 10^{-3}$ & - & 146 & $2.68 \times 10^{-2}$ & 148 & 75.0 & 1.31 & $7.42 \times 10^{-3}$ & 0.8 & \\
\hline
\end{tabular}

Note: $\mathrm{J}_{\mathrm{N}}$ is intensity of natural remanent magnetization (NRM); I is inclination; $\mathrm{MDF}_{\mathrm{N}}$ is mean demagnetizing field for $N R M$; $\mathrm{J}_{\mathrm{A}}$ is intensity of anhysteretic remanent magnetization (ARM); $\mathrm{MDF}_{\mathrm{A}}$ is mean demagnetizing field for $\mathrm{ARM} ; \chi_{0}$ is weak field susceptibility; and $\mathrm{Q}$ is Koenigsberger ratio $\left(\mathrm{J}_{\mathrm{N}} / 0.5 \chi_{0}\right)$. Averages for gabbros and peridotites are given for selected measurements.

a $\%$ indicates the amount of remanence remaining at $1000 \mathrm{Oe}$.
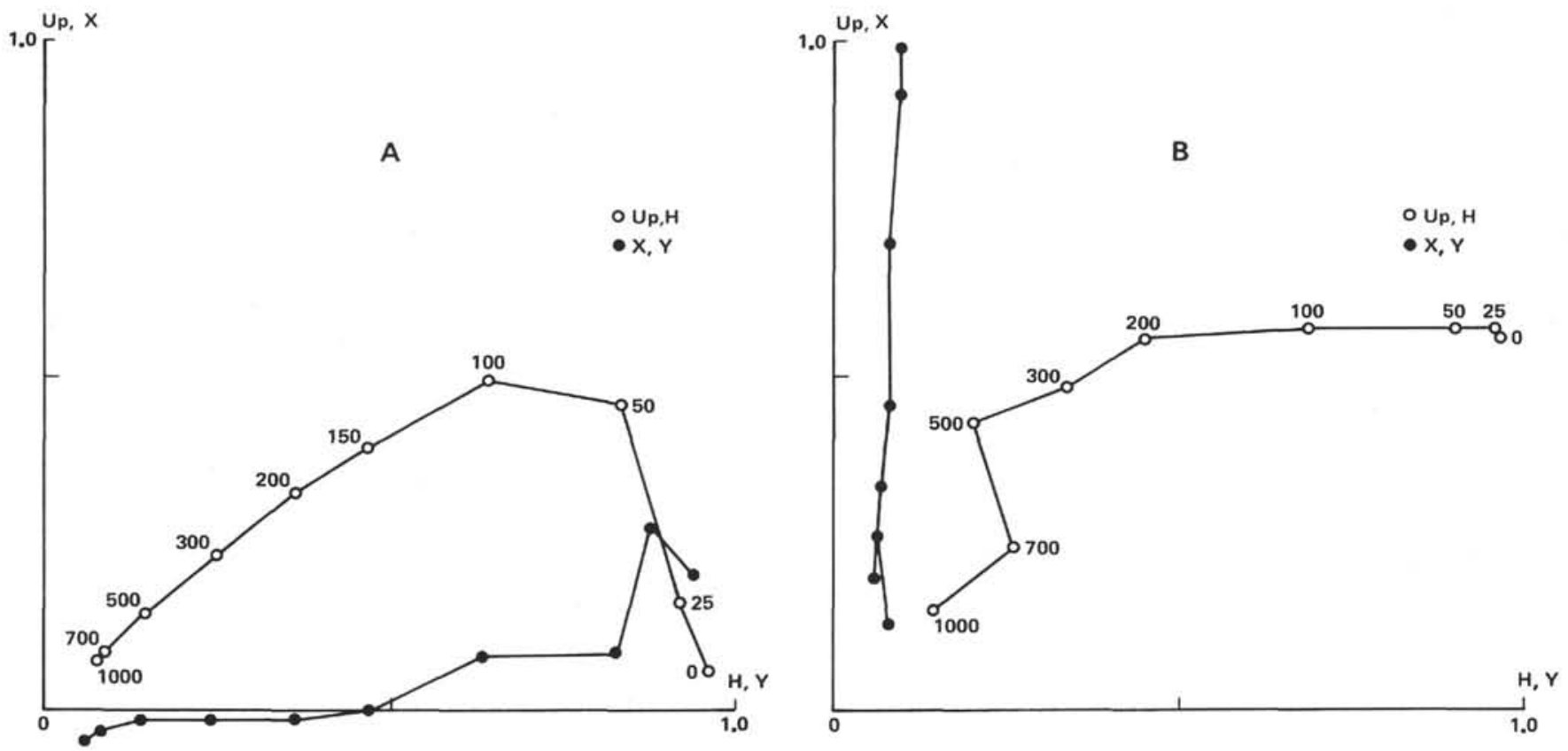

Figure 1. A. Zijderveldt plot of Sample 558-41-2, 61-64 cm showing removal of an apparent viscous component. B. Zijderveldt plot of Sample 560-31, 9-12 cm showing multicomponent behavior. Closed circles represent the $\mathrm{x}$-y component; open circles, the z-horizontal component. Demagnetizing fields are in Oe.

\section{Anhysteretic Remanent Magnetization}

ARM intensities $\left(\mathrm{J}_{\mathrm{A}}\right.$, Table 1) were generally much higher than $\mathbf{J}_{\mathrm{N}}$ (as much as two orders of magnitude). The two exceptions were somewhat atypical: 560-3-1, 9-12 cm, a gabbro with multicomponent behavior, and $558-43-1,8-11 \mathrm{~cm}$, a peridotite with a very low $\mathrm{MDF}_{\mathrm{N}}$.

The MDF's $\left(\mathrm{MDF}_{\mathrm{A}}\right.$, Table 1) were higher than $\mathrm{MDF}_{\mathrm{N}}$ for most of the peridotite samples; the two exceptions were 558-41-2, 54-57 cm and 558-41-2, 61-64 cm. Three of the four gabbros had $\mathrm{MDF}_{\mathrm{A}} / \mathrm{MDF}_{\mathrm{N}}$ larger than 1.0; the exception was $560-3-1,21-24 \mathrm{~cm}$. The exact ratio for the samples from Site 556 cannot be determined because $\mathrm{MDF}_{\mathrm{A}}$ exceeds $1000 \mathrm{Oe}$ (apparently by a substantial amount), but it must be in excess of 2.5 .

\section{Hysteresis Loop Parameters}

The peridotites generally had substantially larger values of saturation magnetization $\left(\mathrm{J}_{\mathrm{s}}\right)$ than the gabbros (Table 2$)$. The gabbro values were fairly consistent $(2-3 \times$ 
Table 2. Intrinsic properties.

\begin{tabular}{|c|c|c|c|c|c|c|c|c|c|c|c|}
\hline \multirow{2}{*}{$\begin{array}{l}\text { Core-Section } \\
\text { (interval in cm) }\end{array}$} & \multirow{2}{*}{$\begin{array}{c}\mathrm{J}_{\mathrm{S}} \\
\left(\mathrm{emu} / \mathrm{cm}^{3}\right)\end{array}$} & \multirow{2}{*}{$\begin{array}{c}\mathrm{J}_{\mathrm{r}} \\
\left(\mathrm{emu} / \mathrm{cm}^{3}\right)\end{array}$} & \multirow{2}{*}{$\begin{array}{c}\mathrm{H}_{\mathrm{c}} \\
(\mathrm{Oe})\end{array}$} & \multirow{2}{*}{$\begin{array}{l}\mathrm{H}_{\mathrm{cr}} \\
(\mathrm{Oe})\end{array}$} & \multirow{2}{*}{$\frac{\mathrm{J}_{\mathrm{r}}}{\mathrm{J}_{\mathrm{S}}}$} & \multirow{2}{*}{$\frac{\mathrm{H}_{\mathrm{cr}}}{\mathrm{H}_{\mathrm{c}}}$} & \multirow[b]{2}{*}{$x_{\mathrm{p}}$} & \multicolumn{2}{|c|}{$\mathrm{T}_{\mathrm{c}}$} & \multirow{2}{*}{$\frac{J_{f}}{J_{i}}$} & \multirow[b]{2}{*}{ Comments } \\
\hline & & & & & & & & Heating & Cooling & & \\
\hline \multicolumn{12}{|l|}{ Hole 556} \\
\hline $14-2,29-32$ & $3.84 \times 10^{-2}$ & $1.30 \times 10^{-2}$ & 309 & 641 & 0.34 & 2.1 & 0.66 & - & - & - & Bulk sample \\
\hline & $9.65 \times 10^{-2}$ & $2.99 \times 10^{-2}$ & 172 & 353 & 0.31 & 2.1 & 1.18 & 375 & 590 & 2.3 & Pyroxene separate \\
\hline & $1.06 \times 10^{-2}$ & - & - & - & - & - & 0.03 & - & - & - & Plagioclase separate \\
\hline $14-2,140-143$ & $3.33 \times 10^{-2}$ & $7.75 \times 10^{-3}$ & 163 & 391 & 0.23 & 2.4 & 0.61 & 560 & 565 & 2.5 & \\
\hline \multicolumn{12}{|l|}{ Hole 558} \\
\hline $41-2,61-64$ & $9.28 \times 10^{-1}$ & $1.35 \times 10^{-1}$ & 134 & 320 & 0.15 & 2.4 & 0.81 & - & - & - & \\
\hline $41-2,54-57$ & $9.75 \times 10^{-1}$ & $1.86 \times 10^{-1}$ & 117 & 197 & 0.19 & 1.7 & 0.85 & 550 & 565 & 0.73 & Sulfides? \\
\hline $42-1,109-112$ & 3.10 & $4.80 \times 10^{-1}$ & 113 & 165 & 0.16 & 1.7 & 1.4 & 560 & 580 & 0.95 & \\
\hline $43-1,8-11$ & 4.03 & $5.40 \times 10^{-1}$ & 92 & 188 & 0.13 & 2.0 & 1.7 & 565 & 580 & 0.97 & \\
\hline \multicolumn{12}{|l|}{ Hole 560} \\
\hline $3-1,9-12$ & $3.30 \times 10^{-2}$ & $5.70 \times 10^{-3}$ & 116 & 266 & 0.17 & 2.3 & 0.81 & 555 & 580 & 1.1 & \\
\hline $3-1,21-24$ & $2.30 \times 10^{-2}$ & $4.40 \times 10^{-3}$ & 84 & 250 & 0.19 & 3.0 & 0.83 & 550 & 580 & 2.0 & \\
\hline $5-1,98-101$ & 3.71 & $8.03 \times 10^{-1}$ & 139 & 203 & 0.22 & 1.5 & 1.05 & 560 & 590 & 0.95 & \\
\hline $5-1,109-112$ & 2.30 & $5.20 \times 10^{-1}$ & 136 & 188 & 0.23 & 1.4 & 0.96 & - & - & - & \\
\hline \multicolumn{12}{|l|}{ Averages } \\
\hline Gabbro & $3.19 \times 10^{-2}$ & $7.71 \times 10^{-3}$ & 168 & 387 & 0.23 & 2.5 & 0.73 & & & & \\
\hline Peridotite & 2.51 & $4.44 \times 10^{-1}$ & 122 & 210 & 0.18 & 1.8 & 1.1 & & & & \\
\hline
\end{tabular}

Note: $\mathrm{J}_{\mathrm{S}}$ is saturation magnetization; $\mathrm{J}_{\mathrm{r}}$ is saturation remanent magnetization; $\mathrm{H}_{\mathrm{c}}$ is coercivity; $\mathrm{H}_{\mathrm{cr}}$ is coercivity of remanence; $\chi_{\mathrm{p}}$ is the paramagnetic susceptibility in emu $\cdot \mathrm{g}^{-1} \cdot \mathrm{Oe}^{-1} \cdot 10^{-5} ; \mathrm{T}_{\mathrm{c}}$ is Curie temperature; $\mathrm{J}_{\mathrm{f}} / \mathrm{J}_{\mathrm{i}}$ is the ratio of final to initial magnetization. Averages for gabbros and peridotites are given for selected measurements. Dashes indicate that measurements could not be performed.

$\left.10^{-2} \mathrm{emu} / \mathrm{g}\right)$. The peridotites fell into two groups. Four had values of about $2 \mathrm{emu} / \mathrm{g}$ and two from Hole 558 were slightly less than $1 \mathrm{emu} / \mathrm{g}$. Coercivities seemed low compared to the MDF and often showed little relation to it. Sample 560-3-1, 21-24 cm had the lowest coercivity of either peridotite or gabbro samples, but it had one of the highest MDF's.

The ratios $\mathrm{J}_{\mathrm{r}} / \mathrm{J}_{\mathrm{s}}$ and $\mathrm{H}_{\mathrm{cr}} / \mathrm{H}_{\mathrm{c}}$ of all samples indicated a pseudo-single domain to small multidomain state. The Site 556 gabbros had relatively high $\mathrm{J}_{\mathrm{r}} / \mathrm{J}_{\mathrm{s}}$ values but those for the other two gabbros were close to peridotite values.

The paramagnetic susceptibilities $\left(\chi_{\mathrm{p}}\right)$ were interesting. Gabbro values were uniformly low $\left(0.6-0.8 \times 10^{-5}\right.$ $\left.\mathrm{emu} \cdot \mathrm{g}^{-1} \cdot \mathrm{Oe}^{-1}\right)$ compared to the peridotites and most basalts (typically, $1.2-1.5 \times 10^{-5} \mathrm{emu} \cdot \mathrm{g}^{-1}$. $\left.\mathrm{Oe}^{-1}\right)$. This is probably due to the presence of plagioclase, as the separate from 556-14-2, 29-32 cm had very low values of $\chi_{\mathrm{p}}$ (Table 2). Peridotites split into the same two groups as defined by $J_{s}$, with the two low $J_{s}$ samples also having low $\chi_{\mathrm{p}}$.

\section{Thermomagnetic Measurements}

The Curie temperature, $T_{c}$, of the peridotites is somewhat below that of pure magnetite $\left(580^{\circ} \mathrm{C}\right)$ for the heating curve and essentially equal to $580^{\circ} \mathrm{C}$ for the cooling curve. It is uncertain just what this represents, because conversion of a nonstoichiometric phase to magnetite normally results in an increase in magnetization rather than the observed decrease. One sample showed an inflection in the heating curve at $350^{\circ} \mathrm{C}$ that may be caused by the breakdown of pyrrhotite.

The gabbros from Site 560 had $T_{c}$ values similar to the peridotites, but the ratio of magnetization before heating to the magnetization after heating $\left(\mathrm{J}_{\mathrm{f}} / \mathrm{J}_{\mathrm{i}}\right)$ was greater than 1.0 for both samples. There are a variety of possible explanations. One is the inversion of a titanomaghemite. The high heating $\mathrm{T}_{\mathrm{c}}$ could be due to low $\mathrm{Ti}$ concentration or a pre-existing partial inversion. Another explanation is the reduction of hemoilmenite caused by heating, probably the result of a combination of a fairly hard vacuum with either backstreaming pump oil or some local reducing agent. There may also be other cations such as $\mathrm{Mg}$ or $\mathrm{Mn}$ involved. Microprobe work is clearly necessary to resolve this question.

One of the Hole 558 samples (558-14-2, 140-143 cm) behaved similarly to samples from Site 560 . The other showed a $T_{c}$ value typical of basaltic titanomaghemites followed by an apparent inversion to a mixed phase. This behavior suggests that at least some gabbros contain high $\mathrm{Ti}$ titanomagnetites that have been altered at low temperatures.

\section{Susceptibility}

One unexpected result of the weak field susceptibility measurements was the fortuitous discovery of a substantial anisotropy (as much as $15 \%$ ). This was true not only for the peridotites, which often had an obvious fabric, but also for the gabbros, which appeared quite homogeneous. Ideally, one would measure the entire susceptibility tensor, but unfortunately this is beyond the capability of our instrument. However, we were able to measure the variation in the vertical plane. An example of the variation of $\chi_{\mathrm{o}}$ with inclination is given in Figure 2. Table 3 summarizes the results for each sample.

With one exception (560-3-1, 9-12 cm), all samples had either essentially vertical or horizontal orientations of maximum susceptibility $\left(\chi_{\max }\right)$. The two samples from Site 556 have mutually perpendicular $\chi_{\max }$ orientations, although they are from the same core and only have a $40^{\circ}$ difference in inclination. The other two sites had 


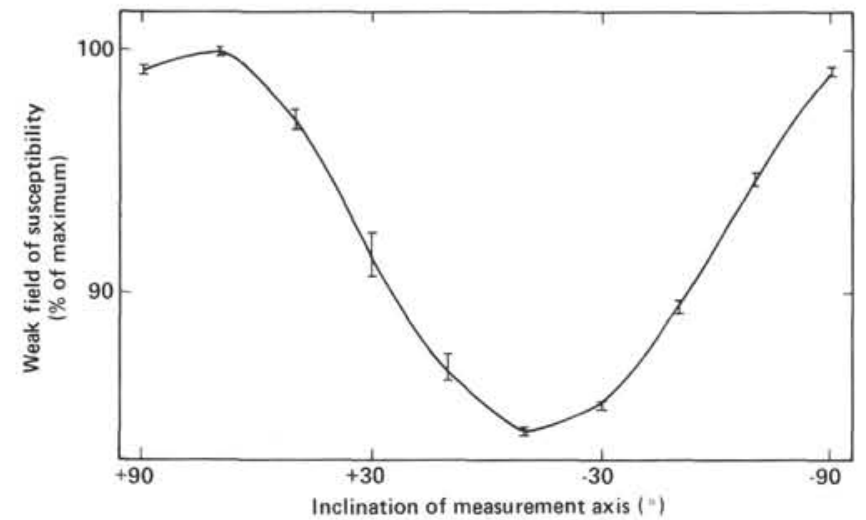

Figure 2. Weak field susceptibility versus sample orientation.

Table 3. Susceptibility anisotropy.

\begin{tabular}{|c|c|c|c|}
\hline $\begin{array}{c}\text { Sample } \\
\text { (interval in } \mathrm{cm} \text { ) }\end{array}$ & $\frac{\chi_{\min }}{\left(\mathrm{emu} \cdot \mathrm{cm}^{-3} \cdot \mathrm{Oe}^{-1}\right)}$ & $\frac{x_{\max }}{\left(\mathrm{emu} \cdot \mathrm{cm}^{-3} \cdot \mathrm{Oe}^{-1}\right)}$ & $\begin{array}{c}\text { Inclination } \\
\left({ }^{\circ}\right)\end{array}$ \\
\hline \multicolumn{4}{|l|}{ Hole 556} \\
\hline $14-2,29-32$ & $8.75 \times 10^{-5}$ & $9.10 \times 10^{-5}$ & 90 \\
\hline $14-2,140-143$ & $9.01 \times 10^{-5}$ & $1.03 \times 10^{-4}$ & 0 \\
\hline \multicolumn{4}{|l|}{ Hole 558} \\
\hline $41-2,61-64$ & $1.17 \times 10^{-3}$ & $1.24 \times 10^{-3}$ & 80 \\
\hline $41-2,54-57$ & $9.54 \times 10^{-4}$ & $9.36 \times 10^{-4}$ & 90 \\
\hline $42-1,109-112$ & $5.32 \times 10^{-3}$ & $6.34 \times 10^{-3}$ & 20 \\
\hline $43-1,8-11$ & $4.71 \times 10^{-3}$ & $5.21 \times 10^{-3}$ & 90 \\
\hline \multicolumn{4}{|l|}{ Hole 560} \\
\hline $3-1,9-12$ & $4.73 \times 10^{-5}$ & $5.51 \times 10^{-5}$ & 50 \\
\hline $3-1,21-24$ & $3.01 \times 10^{-5}$ & $3.14 \times 10^{-5}$ & 0 \\
\hline $5-1,98-101$ & $4.19 \times 10^{-2}$ & $5.32 \times 10^{-2}$ & 20 \\
\hline $5-1,109-112$ & $5.07 \times 10^{-3}$ & $5.92 \times 10^{-3}$ & 20 \\
\hline
\end{tabular}

three samples with similar orientations and one odd one. Hole 558 had $90^{\circ}$ as the dominant direction whereas the direction for Site 560 was close to horizontal.

\section{Microscopy}

In addition to magnetic measurements, polished thin sections of all samples were studied in both transmitted and reflected light. The results reported here are based on a relatively brief examination of the sections and should be regarded as preliminary and tentative.

Sample 556-14-2, 29-32 cm was a partially serpentinized gabbro with homogeneous magnetite or titanomagnetite as the dominant phase with little or no hematite present. It was found in two locations in the sample. Most had acicular (or tabular) habit and occurred along the twin (or cleavage) planes of partially serpentinized pyroxenes (Fig. 3). The rest was found as acicular inclusions in plagioclase grains (Fig. 4).

Sample 556-14-2, 140-143 cm was somewhat different, proximity to the previous sample notwithstanding. Little or no magnetite was present in the plagioclase even though it was common in the preceding sample. Magnetite was found in partially serpentinized pyroxenes, as before, but it also contained lamellar hematite (Fig. 5).

The serpentinites from Hole 558 could be grouped into two pairs on optical as well as magnetic grounds. The two samples from Core 558-41 were generally tan. Mag-

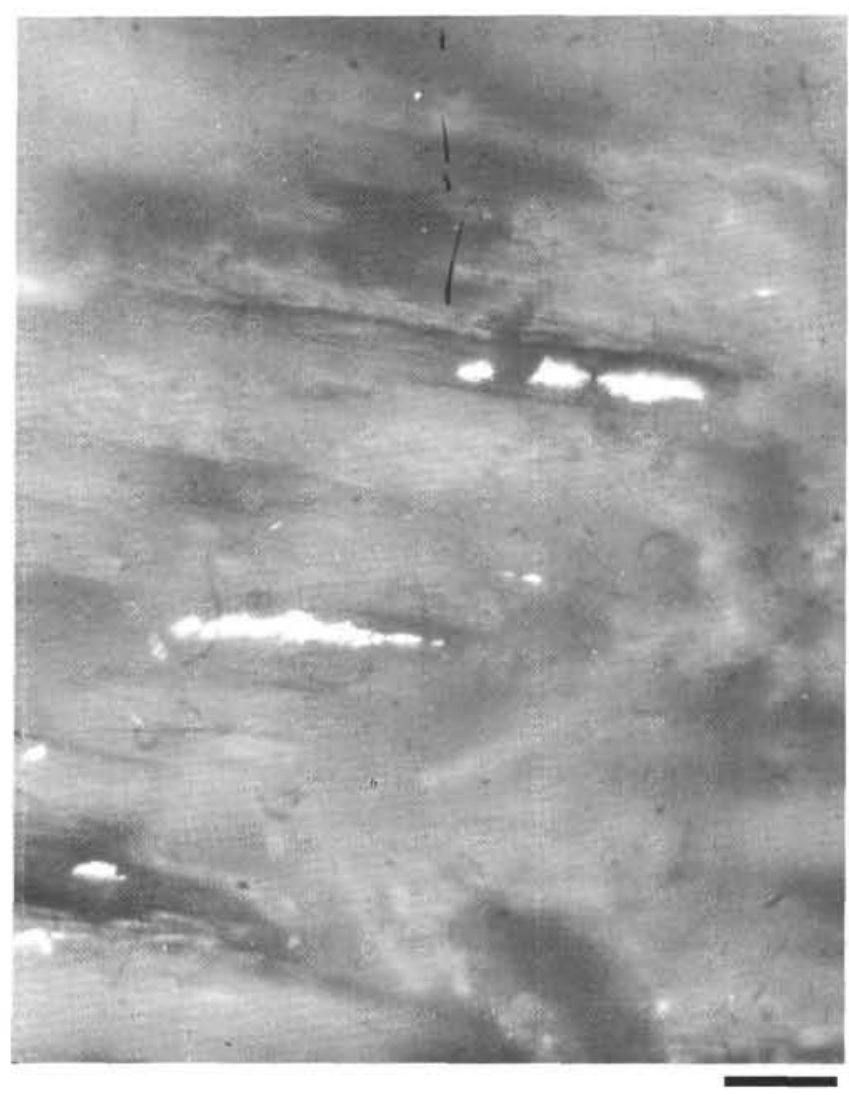

Figure 3. Elongated magnetite grains in altered pyroxene. Reflected light. Scale bar $=100$ microns.

netite was found in two locations, along twin planes in relict pyroxenes (often not fully serpentinized) and as granular masses along grain boundaries (Fig. 6). Small amounts of what appeared to be hematite were also present as small $(10-15 \mu \mathrm{m})$ discrete grains and perhaps as pigment.

The second pair of samples, 558-42-1, 109-112 cm and 558-43-1, 8-11 cm, were dark green and looked like conventional serpentinite. Under the microscope, the only remnants of the original minerals were pseudomorphs of pyroxene. Magnetite was found as abundant granular clusters along grain boundaries. What magnetite was found in the relict pyroxenes was in the form of clusters of grains rather than the discrete elongated grains seen in the partially serpentinized samples.

Site 560 had two gabbros and two serpentinites within a few tens of meters. The upper two samples were gabbros (560-3-1, 9-12 cm and 560-3-1, 21-24 cm) that were significantly different in appearance than those from Site 556 , being a fairly homogeneous dark green, whereas the Site 556 gabbros were gray with $2-3 \mathrm{~mm}$ brown pyroxenes. The plagioclase was extensively altered to sericite and showed little evidence of magnetite inclusions. Magnetite was located largely along twin planes of partially serpentinized pyroxene as seen in the previous sample. There appeared to be little or no hematite, and both samples contained minor sulfides. There was a substantial difference in silicate grain size, however; 560- 


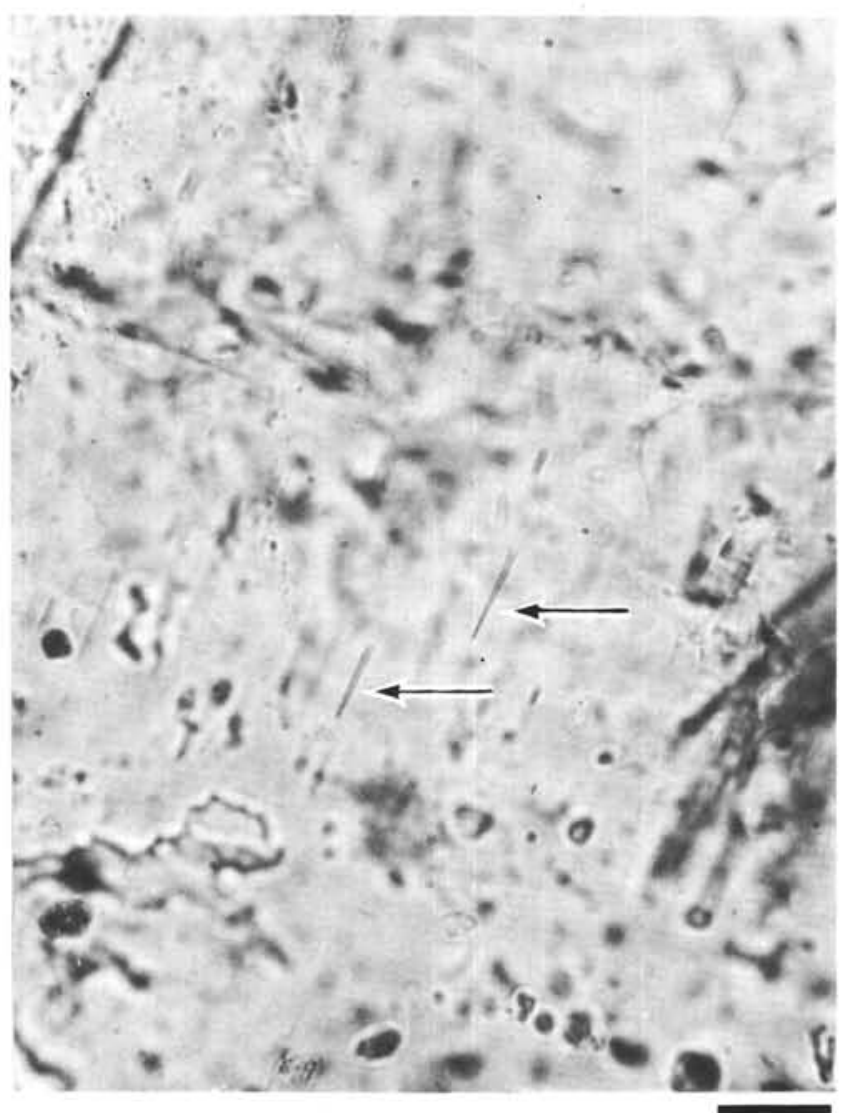

Figure 4. Magnetite needles in plagioclase (arrows). Transmitted light; scale bar $=100 \mu \mathrm{m}$.

$3-1,9-12 \mathrm{~cm}$ had relatively large $(\leq 5 \mathrm{~mm})$ grains, whereas 560-3-1, 21-24 cm had much smaller ( $\leq 1-2 \mathrm{~mm})$ grains.

The peridotites were similar to the latter two samples from Site 558. Magnetite occurred as granular masses along grain boundaries and as a few large $(\sim 1 \mathrm{~mm})$ grains. Some hematite was present, generally in contact with magnetite. Sulfides were also present, sometimes in contact with magnetite.

Low temperature alteration did not appear to be present in any of the samples, although thermomagnetic measurements suggest that a more thorough examination of better quality slides may change this conclusion.

Some of the serpentinites had an obvious fabric in thin section defined by the grain boundary magnetite that generally had the same orientation as $\chi_{\max }$ (Fig. 7). Visual inspection of the cores suggests that a foliation rather than a lineation is defined by this fabric. This correspondence implies that $\chi_{\max }$ is related to the stress regime these samples have been subjected to and might be useful in defining petrofabrics.

\section{DISCUSSION}

Probably the most notable thing about these samples is their lack of homogeneity, even on the scale of $1 \mathrm{~m}$. This raises some questions as to how well these rocks represent their deep crustal counterparts and the tecton-

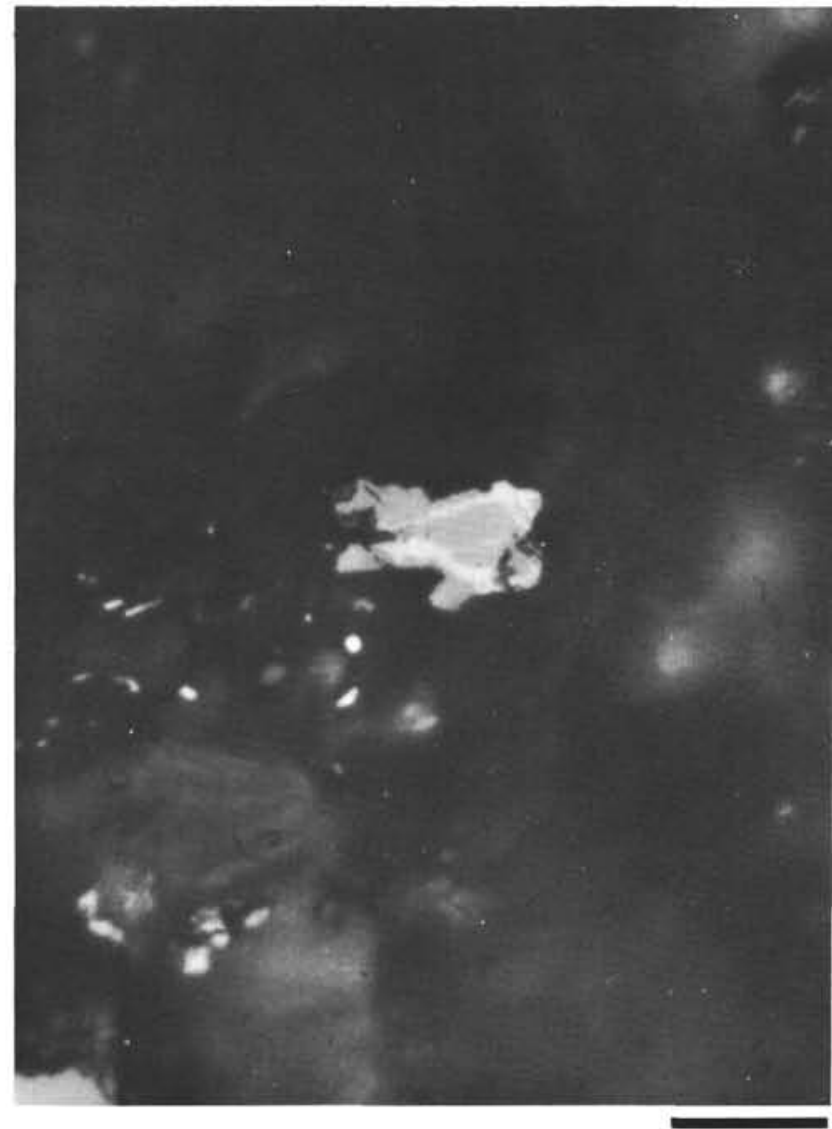

Figure 5. Lamellar hematite in magnetite matrix. Reflected light; scale bar $=50 \mu \mathrm{m}$.

ic and chemical processes involved in bringing them to the surface. Unfortunately, the small number of samples makes any conclusion tentative.

The Site 556 gabbros are from the same core and have similar NRM and silicate mineralogy. However, their opaque mineralogy (in particular, the presence or absence of hematitte and of magnetite inclusions in plagioclase and intrinsic magnetic parameters were significantly different. Virtually the converse was true for the two gabbros from Site 560. Intrinsic magnetic parameters and opaque mineralogy were similar, but NRM values differed by more than an order of magnitude. The grain sizes of the silicate phases were also significantly different.

The ultramafics from Hole 558 broke down into two pairs of similar samples. There were significant differences between the pairs, however, both in petrology and magnetic character. They appear to have been similar originally, but the Core 558-41 samples have been altered to a lesser degree. The opaque mineralogy suggests that this difference in alteration is also responsible to a large extent for the magnetic differences, in particular, the fact that NRM values differ by more than can be explained by intrinsic parameters. However, the difference in NRM values for the Site 560 ultramafics, which are otherwise very similar, indicates that other factors must also be operating. 


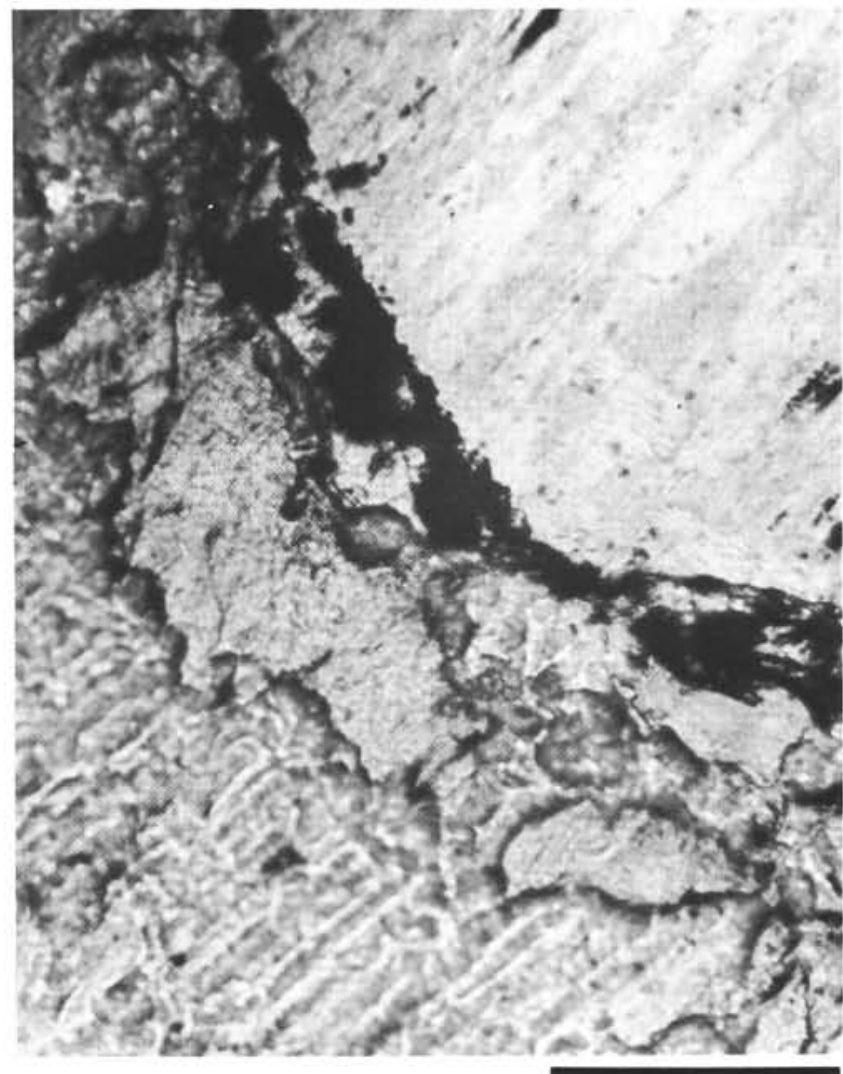

Figure 6. Granular magnetite along grain boundaries. Transmitted light; scale bar $=100 \mu \mathrm{m}$.

There seems to be three possible origins of this heterogeneity, not necessarily mutually exclusive; an initially homogeneous source that suffered varying degrees of alteration during and/or after emplacement, a somewhat heterogeneous source that was tectonically mixed by the emplacement process, and a source that was essentially similar to the samples recovered.

Some degree of source heterogeneity seems necessary to explain the abundance of magnetite in plagioclase in one of the Site 556 gabbros and its absence in the other, as it is presumably a primary phase. The difference in both NRM and $\chi_{\max }$ inclination suggests that tectonic disruption did occur on a fine scale but says nothing about the possibilities of large-scale mixing versus finescale inhomogeneities in the source area.

The opposite inclinations of the two pairs of Hole 558 serpentinites may simply be a fortuitous tectonic (or shipboard) occurrence or they may reflect a field reversal. They may also represent self-reversal, although the magnetic mineralogy makes this unlikely. The fact that normal and reversed inclinations are seen in the overlying basalts indicates that a field reversal is at least plausible. The similarity of $\chi_{\max }$ inclinations for three of the four samples suggests that they may not have been tectonically rotated relative to each other, although a $180^{\circ}$ rotation is possible. If these samples do represent different geomagnetic polarities, then the similarity of inclination indicates that remanence was probably acquired

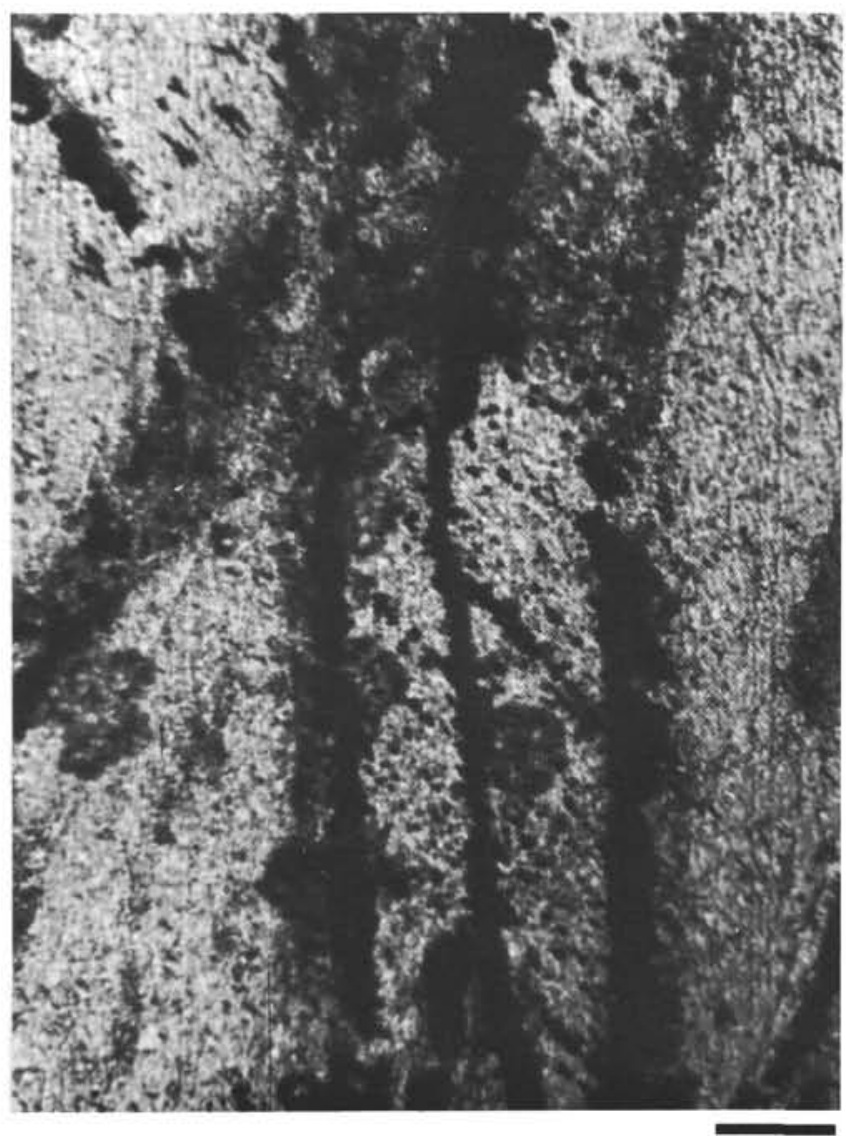

Figure 7. Aligned clusters of granular magnetite. Transmitted light; scale bar $=1 \mathrm{~mm}$.

after emplacement and that the samples were magnetized at least 2000-3000 yr. apart. As the remanence appears to be chemical in origin, it would also indicate significant alteration after emplacement. If this is the case, it is difficult to ascertain what relation these samples bear to their counterparts at depth.

Given the difference in both petrology and alteration state for the Site 560 samples, some tectonic mixing seems probable, although variable alteration during or after emplacement may also have occurred. The similarity in NRM and three of the four $\chi_{\max }$ inclinations may be a tectonic accident but, more likely, may also be related to remanence acquisition that postdates emplacement. As with Hole 558, this would imply significant postemplacement alteration.

It seems likely that the bulk of the remanence in these samples is of chemical rather than thermal origin. Most of the magnetic minerals seem to have been produced as a result of serpentinization, which takes place at relatively low temperatures $\left(<400^{\circ} \mathrm{C}\right)$. As discussed in the previous paper (Smith and Banerjee, this volume), marked differences between $\mathrm{J}_{\mathrm{A}}$ and $\mathrm{J}_{\mathrm{N}}$ and $\mathrm{MDF}_{\mathrm{A}}$ and $\mathrm{MDF}_{\mathrm{N}}$ also suggest a chemical remanent magnetization. It is difficult to determine just when this alteration occurred, so that the relation of the magnetic properties of these samples to their sources is unclear at best. 
The origin of susceptibility anisotropy is an interesting question. In the peridotite, it seems to be controlled by the orientation of the elongated clusters of magnetite grains, which are in turn controlled by the orientation of serpentine crystals. Thus, this orientation should be a reasonably accurate reflection of the deformation of the sample, at least qualitatively.

The gabbros hold few or no grain boundary magnetite clusters, but rather occur as elongated inclusions in pyroxene grains, and their orientation is crystallographically controlled. One possible connection between this orientation and deformation is suggested by Kolle and Blacic (1982), who show that clinopyroxene can respond to stress by mechanical twinning on (100) planes. If serpentinization occurs initially along these deformationally defined planes, it would then lead to a magnetic fabric defined by the magnetite precipitated along the planes.

The results of these studies are consistent with those of plutonic rocks recovered on DSDP Legs 37 and 45 (e.g., Dunlop and Prevót, 1982). We do not see any highly magnetized gabbros, but this may well be a sampling artifact. The peridotites are also generally similar. No weakly magnetized samples were found but, again, this may be due to insufficient sampling. Davis (1981) suggested magnetite inclusions in plagioclase as a major contributor to gabbro remanence. These were seen in only one of the our Leg 82 gabbros, indicating that other factors must also be important.

As the magnetic properties of these samples are controlled by alteration, what we see may simply reflect the peculiarities of the tectonic and chemical environment that placed them so close to the surface, making comparison to ophiolite studies questionable (e.g., Banerjee, 1980). With that caveat, the magnetic properties of the gabbros are comparable to the high level gabbros of the Samail ophiolite (Luyendyk and Day, 1982) and the greenschist facies gabbros of the Bay of Islands ophiolite (Swift and Johnson, 1984). The peridotites are comparable with the more strongly magnetized ophiolite samples.

To the extent that these samples may be representative of the deep crust, neither type would probably contribute much to magnetic anomalies. The gabbros are simply too weakly magnetized. The peridotites are strongly magnetized but their low stability and small Q make them marginal candidates at best.

\section{SUMMARY}

1. The NRM of these samples seems to be primarily chemical in origin and controlled by the degree to which the samples are serpentinized. Generally, gabbros have lower $\mathbf{J}_{\mathrm{N}}$ than ultramafics but there is some overlap.

2. There is considerable variation in both magnetic properties and mineralogy/petrology, even for closely spaced samples. This suggests some combination of source heterogeneity, tectonics, and alteration during and after emplacement. The relation of these rocks to those of the deep crust is thus problematic.

3. The samples show a significant susceptibility anisotropy, at least in a vertical plane, which appears to be related to the deformation of the rocks.

4. The samples generally are comparable both to previous DSDP studies and to ophiolite studies. However, the uncertain relation of the samples to their source makes such comparisons somewhat speculative.

\section{ACKNOWLEDGMENTS}

We would like to thank Wendy Tormanen and Yvonne Meeks for their assistance with some of the measurements. Valuable assistance was also rendered on many occasions by Jim Marvin. We would also like to thank our reviewers, S. Beske-Diehl, B. Moskowitz, and R. Merrill, for many helpful comments and criticisms. This work was performed under NSF Grants OCE-8018692 and OCE-8214652; it is publication Number 1064 of the School of Earth Science, Department of Geology and Geophysics, University of Minnesota.

\section{REFERENCES}

Banerjee, S. K., 1980. Magnetism of the ocean crust-evidence from ophiolite complexes. J. Geophys. Res., 85:3557-3566.

Davis, K. E., 1981. Magnetic rods in plagioclase as the primary carrier of stable. NRM in ocean floor gabbros. Earth Planet. Sci. Lett., 55:190-198.

Dunlop, D. J., and Prevót, M., 1982. Magnetic properties and opaque mineralogy of drilled submarine intrusive rocks. Geophys. J. R. Astron. Soc., 69:763-802.

Kolle, J. J., and Blacic, J. D., 1982. Deformation of single crystal clinopyroxene, 1, Mechanical twinning of diopside and hedenbergite. J. Geophys. Res., 87:4019-4034.

Luyendyk, B. P., and Day, R., 1982. Paleomagnetism of the Samail ophiolite, Oman, 2, The Wadi Kadir gabbro section. J. Geophys. Res., 84:10,903-10,917.

Swift, B. A., and Johnson, H. P., 1984. Magnetic properties of the Bay of Islands ophiolite suite and implications for the magnetization of the ocean crust. J. Geophys. Res., 89:3291-3308.

Date of Initial Receipt: 28 October 1983

Date of Acceptance: 31 January 1984 